\title{
Cultivation of vetiver in saline tailings contaminated with arsenic under phosphorus doses
}

\author{
Lorena A. de O. P. Guimarães ${ }^{1}$, Luiz E. Dias ${ }^{2}$, Igor R. de Assis² \& Amanda L. Cordeiro ${ }^{3}$ \\ ${ }^{1}$ Instituto Capixaba de Pesquisa, Assistência Técnica e Extensão Rural/Centro Regional de Desenvolvimento Rural Centro Serrano. Domingos Martins, \\ ES. E-mail: lorena.prata@hotmail.com (Corresponding author) \\ ${ }^{2}$ Universidade Federal de Viçosa/Departamento de Solos. Viçosa, MG. E-mail: ledias@ufv.br; igor.assis@ufv.br \\ ${ }^{3}$ Instituto Nacional de Pesquisas da Amazônia. Manaus, AM. E-mail: amanda_longhi@hotmail.com
}

\section{Key words:}

sulfide substrate

gold mining

environmental reclamation

Chrysopogon zizanioides

\begin{abstract}
A B S T R A C T
The processing of gold ores exploited in Paracatu, MG, generates tailings that are challenging for revegetation, mainly because of the high content of arsenic and salinity. Aiming at the revegetation of the area of disposal of these tailings, the objective of this study was to evaluate the effects of phosphorus doses on vetiver plants (Chrysopogon zizanioides) and on the planting substrate, which consisted of tailings from the processing of ore named B1, exploited in Paracatu, with water restriction. Vetiver was grown for four months in the substrate under doses of $0,140,280,560$ and $1280 \mathrm{mg} \mathrm{kg}^{-1}$ of $\mathrm{P}_{2} \mathrm{O}_{5}$. Increasing doses of phosphorus improved the chemical characteristics of the substrate. However, the highest dose $\left(1280 \mathrm{mg} \mathrm{kg}^{-1} \mathrm{P}_{2} \mathrm{O}_{5}\right.$ ) resulted in higher toxicity of arsenic for the plants. Under the evaluated conditions, the dose of $560 \mathrm{mg} \mathrm{kg}^{-1}$ of $\mathrm{P}_{2} \mathrm{O}_{5}$ is the most suitable for the fertilization of vetiver and, therefore, also for the revegetation of the substrate. Vetiver survives under low availability of water in the tailings.
\end{abstract}

\section{Palavras-chave:}

substrato sulfetado mineração de ouro recuperação ambiental Chrysopogon zizanioides

\section{Cultivo de vetiver em um rejeito salino contaminado com arsênio sob doses de fósforo}

\section{R E S U M O}

O beneficiamento dos minérios de ouro explotados em Paracatu, MG, gera rejeitos com características limitantes à revegetação, principalmente pelo elevado teor de arsênio e salinidade. Visando à revegetação da área de depósito desses rejeitos, o objetivo deste trabalho foi avaliar os efeitos de doses de fósforo sobre plantas de vetiver (Chrysopogon zizanioides) e sobre o substrato de plantio, que consistiu em um rejeito proveniente do beneficiamento do minério denominado B1, explotado em Paracatu, com restrição hídrica. O vetiver foi cultivado durante quatro meses no substrato sob as doses de 0,140 , 280, 560 e $1280 \mathrm{mg} \mathrm{kg}^{-1}$ de $\mathrm{P}_{2} \mathrm{O}_{5}$. Com o aumento das doses de fósforo houve melhoria nas características químicas do substrato, porém a dose mais elevada (1280 mg kg-1 $\mathrm{de}^{-}$ $\mathrm{P}_{2} \mathrm{O}_{5}$ ) propiciou maior toxicidade de arsênio nas plantas. Nas condições avaliadas, a dose de $560 \mathrm{mg} \mathrm{kg}^{-1}$ de $\mathrm{P}_{2} \mathrm{O}_{5}$ é a mais adequada para a adubação do vetiver, visando à revegetação do substrato. $\mathrm{O}$ vetiver sobrevive à baixa disponibilidade de água no rejeito. 


\section{INTRODUCTION}

Some ores exploited for gold production may contain toxic elements, such as arsenic (As), in their composition, causing environmental problems. In Brazil, gold and iron mining has contributed to the dispersion of As and its entry in the food chain (Campos et al., 2006).

The tailings produced in the processing of gold ores exploited in Paracatu, MG, Brazil, have limiting characteristics to plant growth, especially acidity, salinity and high As concentrations, which compromise the process of revegetation of the basin where they are disposed. A practice that can facilitate the establishment of plants in these tailings is phosphate fertilization.

The addition of $\mathrm{P}$ has been reported as inhibitor of As absorption (Lei et al., 2012). Phosphate and arsenate are chemically similar and share the same membrane transporters in root cells, and the transporters have higher affinity for the phosphate (Tu \& Ma, 2003; Zhao et al., 2008).

Besides phosphate fertilization, plants tolerant to As and to salinity may have promising responses for the revegetation of tailings. One species with desirable characteristics to start the process of revegetation is Chrysopogon zizanioides (vetiver). The species, besides having high biomass production, has high tolerance and capacity of accumulation of contaminants (Singh et al., 2007).

In this context, this study aimed to evaluate the effects of $\mathrm{P}$ doses on vetiver plants and on the planting substrate, which consisted of tailings from the processing of one of the gold ores exploited in Paracatu, MG, Brazil, subjected to water restriction.

\section{Material ANd Methods}

The substrate consisted of tailings from the processing of $\mathrm{B} 1$ ore, which is a highly weathered phyllite, with sulfide contents around $3.0 \mathrm{~g} \mathrm{~kg}^{-1}$, collected in Paracatu, MG, Brazil. Three samples of the substrate were collected for its initial characterization, through the determination of $\mathrm{pH}$ in water, available contents of $\mathrm{P}, \mathrm{K}, \mathrm{Fe}, \mathrm{Mn}$ and $\mathrm{S}$, exchangeable contents of $\mathrm{Na}, \mathrm{Ca}^{2+}, \mathrm{Mg}^{2+}$ and $\mathrm{Al}^{3+}, \mathrm{CEC}$ at $\mathrm{pH}$ 7.0, exchangeable sodium percentage, content of organic matter (OM) (EMBRAPA, 1997), reminiscent P (Farias et al., 2009), field capacity (FC) at $-10 \mathrm{kPa}$, substrate density (Ds) and particle density (Dp), through the methods of graduated cylinder and volumetric flask (EMBRAPA, 1997), respectively, and granulometry (Ruiz, 2005). The content of available As was extracted with Mehlich 3 extractor and quantified through inductively coupled plasma optical emission spectrometry (ICP-OES), at the wavelength of $193.696 \mathrm{~nm}$.

Each experimental plot consisted of a column made of PVC pipe ( $45 \times 15 \mathrm{~cm}$, height $\mathrm{x}$ diameter), filled with substrate. The $5 \mathrm{~cm}$ of the upper portion were not filled with substrate and only served as a protection against the loss of material. Each column had a utilizable volume of $7.07 \mathrm{dm}^{3}$.

The substrate for the filling of the columns was air-dried and passed through a $4-\mathrm{mm}$-mesh sieve. In each column, $7.8 \mathrm{~kg}$ of dried substrate were added, deducting the residual moisture obtained by the thermogravimetric method (EMBRAPA, 1997), to obtain the density of $1.10 \mathrm{~kg} \mathrm{dm}^{-3}$.

The substrate of each plot was homogenized with $\mathrm{CaCO}_{3}$ and $\mathrm{MgCO}_{3}$ (Analytical Reagent - $\mathrm{AR}$ ), at the Ca:Mg proportion of $4: 1$. The amount of acidity corrective was determined by the method of $\mathrm{Al}^{3+}$ neutralization and the increase of $\mathrm{Ca}^{2+}+\mathrm{Mg}^{2+}$ contents, corresponding to $1 \mathrm{t} \mathrm{ha}^{-1}$. Then, the substrate was moistened with deionized water in amount equivalent to $60 \%$ FC and incubated in a plastic bag for fourteen days.

After the incubation period, the doses of 0, 140, 280, 560 and $1280 \mathrm{mg} \mathrm{kg}^{-1}$ of $\mathrm{P}_{2} \mathrm{O}_{5}$ were added in the form of monobasic ammonium phosphate and homogenized in the entire volume of the substrate. The substrate was then deposited in the columns and the vetiver seedlings, with previously washed roots, were planted (one plant per column). The seedlings were cut at the height of $30 \mathrm{~cm}$ to standardize their mass.

The substrate was fertilized through the addition of 340 , $120,0.833$ and $0.266 \mathrm{mg} \mathrm{kg}^{-1}$ of N, K, B and Mo, respectively, in all treatments. The doses of $\mathrm{N}$ and $\mathrm{K}$ were divided into two applications, half at 7 days after planting (DAP) and half at 15 DAP. Fertilization with B and Mo was performed in a single dose, at 15 DAP. In the $\mathrm{N}$ fertilization, the amount of $\mathrm{N}$ added in the monobasic ammonium phosphate was deducted. The nutrients were supplied with ammonium nitrate (AR), potassium chloride (AR), sodium borate (AR) and ammonium molybdate (AR).

The experiment was conducted for four months in a greenhouse with randomized block design and four replicates. In the first, second, third and fourth months, 2.06, 0.85, 0.20 and $0.065 \mathrm{~L}$ of deionized water were added to each column, divided in 12, 9, 2 and 1 application, respectively. The reduction in the amount and frequency of irrigation aimed to promote water restriction.

After the experimental period, plants were separated into shoots and roots. Since it was not possible to measure root length (because they fragmented during the separation from the substrate), the root system was analyzed separately in the layers of 0-20 and 20-40 cm, which allowed to observe where the roots were concentrated.

The roots were washed with deionized water with a $0.1 \%$ neutral detergent solution and again with deionized water; then, they were washed with $3 \% \mathrm{HCl}$ solution and with deionized water. The shoots were washed only with deionized water; after washing, the plant material was dried in a forcedair oven at $60^{\circ} \mathrm{C}$ until constant mass for the determination of dry matter.

The plant samples were subjected to nitric-perchloric digestion (Tedesco et al., 1995) for the determination of As and $\mathrm{P}$ contents in the biomass; the quantification was performed through ICP-OES and the total amounts of the elements in the biomass were calculated based on their contents and on the dry matter production. The analyses of the samples of the substrate collected in the layers of $0-10,10-20$ and $20-40 \mathrm{~cm}$ were performed using the same methodologies of the initial characterization, with alteration in the determination of the content of available $\mathrm{P}$, which was extracted using the Mehlich 3 extractor and quantified through ICP-OES, at the wavelength of $214.914 \mathrm{~nm}$. In 
addition, the electrical conductivity (EC) was determined in the saturation paste extract (EMBRAPA, 1997).

The data were subjected to analysis of variance through $\mathrm{F}$ test and regression to verify the response of the variables to the $\mathrm{P}$ doses. Linear and quadratic regression models were tested.

\section{Results AND Discussion}

Due to its mineralogical nature, the substrate showed low fertility with low contents of $\mathrm{P}, \mathrm{Ca}^{2+}, \mathrm{Mg}^{2+}$ and $\mathrm{B}$, although $\mathrm{Zn}, \mathrm{Fe}, \mathrm{Mn}$ and S contents were high (Alvarez V. et al., 1999) (Table 1). The As content was very high, well above the prevention value of $15 \mathrm{mg} \mathrm{kg}^{-1}$ established by the CONAMA Resolution no 420 (Brasil, 2009), above which there may be harmful alterations in the quality of the soil and groundwater. In addition, the predominance of silt fraction and the low CEC promotes low capacity of adsorption of cations in the substrate.

The OM content in the initial characterization of the substrate was possibly overestimated. The method used in the determination of the organic carbon content is based on the oxidation of this element (EMBRAPA, 1997) and, because of this, the result may suffer interference from other elements that are in reduced forms and that can be equally oxidized, such as $\mathrm{Fe}, \mathrm{Mn}$ and S, overestimating the content of organic carbon.

The dry matter production of vetiver did not respond significantly to the applied $\mathrm{P}$ doses (Table 2). Root dry matter tended to be higher in the surface layer, $0-20 \mathrm{~cm}$.

The characteristic symptoms of As toxicity in plants are wilting of leaves, slow growth, leaves with necrosis and purple color and, finally, the death of the plant (Melo et al., 2009; Schneider et al., 2012). Plants subjected to the highest P dose showed the greatest damages similar to those of As toxicity, with chlorosis and necrosis in young leaves and necrosis in all older leaves. In the other treatments, especially at the dose of 0 , the leaves showed dark green color, which can be a symptom of P deficiency (Choi et al., 2013), and necrosis only on the tips. In spite of that, the plant constantly produced new leaves and remained alive.
Visually, it was observed that, in plots with doses lower than or equal to $560 \mathrm{mg} \mathrm{kg}^{-1}$ of $\mathrm{P}_{2} \mathrm{O}_{5}$, the main root was thicker and managed to grow until $40 \mathrm{~cm}$ depth, becoming denser at the bottom of the columns. Differently, the roots at the highest $\mathrm{P}$ dose did not become denser at the bottom of the columns, remaining concentrated in the surface - $91 \%$ of the total root dry matter concentrated in the layer of $0-20 \mathrm{~cm}$. In the treatments with $0,140,280$ and $560 \mathrm{mg} \mathrm{kg}^{-1}$ of $\mathrm{P}_{2} \mathrm{O}_{5}$, respectively, $76,58,61$ and $65 \%$ of the total root dry matter remained concentrated in the surface layer.

The damage on root growth may be an indication of the sensitivity of the plant to a toxic element. The reduction in the length of roots and shoots and the loss of root ramifications are symptoms of exposure of plants to As (Liu et al., 2005; Moreno-Jiménez et al., 2012). In the present study, the lower proportion of root biomass in the layer of $20-40 \mathrm{~cm}$, at the highest $\mathrm{P}$ dose, may result from the toxicity of As.

The lower damages observed in the leaves and the greater deepening of the roots in the substrate, although it is a strategy of the plant to increase its ability to access and absorb $\mathrm{P}$ (Hinsinger et al., 2015), suggest that doses lower than or equal to $560 \mathrm{mg} \mathrm{kg}^{-1}$ of $\mathrm{P}_{2} \mathrm{O}_{5}$ reduced As toxicity.

The contents and total amounts of As in the dry matter increased with the doses of $\mathrm{P}$ (Figure 1), corroborating $\mathrm{Tu}$ \& Ma (2003), who observed that the addition of phosphate to the soil increased the accumulation of arsenate by Pteris vittata. The dose of $1280 \mathrm{mg} \mathrm{kg}^{-1}$ of $\mathrm{P}_{2} \mathrm{O}_{5}$ may have resulted in increase of As toxicity due to the increment in its absorption and translocation, which means that plants can become less tolerant to As when subjected to the highest $\mathrm{P}$ dose, since the tolerance is related to the capacity of preventing the absorption and translocation of the pollutant.

The study was based on the hypothesis that the highest $\mathrm{P}$ dose would reduce As absorption, since the transporters in the roots have greater affinity for the phosphate (Zhao et al., 2008), which was not confirmed. Although P was absorbed in greater amounts compared with As, the increase in $\mathrm{P}$ doses resulted in increments in the absorption not only of $\mathrm{P}$, but also of As, which may have occurred due to the mass effect

Table 1. Initial characterization of the substrate used for the planting of vetiver

\begin{tabular}{|c|c|c|c|c|c|c|c|c|c|c|}
\hline \multirow{2}{*}{$\begin{array}{c}\mathrm{pH} \\
\left(\mathrm{H}_{2} \mathrm{O}\right)\end{array}$} & $\mathbf{P}$ & $\mathrm{K}$ & $\mathrm{Na}$ & $\mathrm{Ca}^{2+}$ & $\mathrm{Mg}^{2+}$ & $\mathrm{Al}^{3+}$ & CEC & \multirow{2}{*}{$\begin{array}{l}\text { ESP } \\
\text { (\%) }\end{array}$} & \multirow{2}{*}{$\begin{array}{c}\mathrm{OM} \\
\left(\operatorname{dag~kg}^{-1}\right)\end{array}$} & \multirow{2}{*}{$\begin{array}{l}\text { P-rem } \\
\left(\mathrm{mg} \mathrm{L}^{-1}\right)\end{array}$} \\
\hline & \multicolumn{3}{|c|}{$\left(\mathrm{mg} \mathrm{dm}{ }^{-3}\right)$} & \multicolumn{4}{|c|}{$\left(\mathrm{cmol}_{\mathrm{c}} \mathrm{dm}^{-3}\right)$} & & & \\
\hline 4.57 & 21 & 68 & 15.2 & 0.79 & 0.35 & 0.10 & 1.78 & 3.71 & 0.91 & 55.1 \\
\hline $\mathrm{Fe}$ & $M n$ & $S$ & As & \multirow{3}{*}{$\begin{array}{c}F C \\
\left(\mathbf{g ~ g}^{-1}\right) \\
0.391\end{array}$} & Ds & $D p$ & CS & FS & Silt & Clay \\
\hline & & & & & \multicolumn{2}{|c|}{$\left(\mathrm{kg} \mathrm{dm}^{-3}\right)$} & \multicolumn{4}{|c|}{$\left(\mathrm{kg} \mathrm{kg}^{-1}\right)$} \\
\hline 1.026 & 13 & 142 & 112 & & 1.10 & 2.40 & 0.020 & 0.239 & 0.705 & 0.036 \\
\hline
\end{tabular}

CEC - Cation exchange capacity at pH 7.0; ESP - Exchangeable sodium percentage = Na x 100 / CEC; OM - Organic matter; P-rem - Reminiscent phosphorus; FC - Field capacity; Ds -

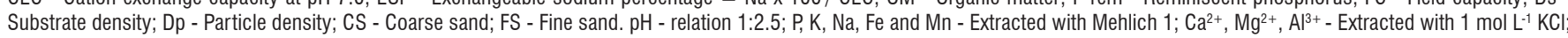
OM - Organic carbon x 1.724; S: - Extracted with monocalcium phosphate in acetic acid; As - Extracted with Mehlich 3 and determined through ICP-OES

Table 2. Mean values of shoot and root dry matter (in the layers of 0-20 and 20-40 cm) of vetiver plants under applied phosphorus doses

\begin{tabular}{|c|c|c|c|c|c|}
\hline \multirow{2}{*}{$\begin{array}{c}\text { Dose of } \mathrm{P}_{2} \mathrm{O}_{5} \\
\left(\mathrm{mg} \mathrm{kg}^{-1}\right)\end{array}$} & Shoots & Roots $0-20 \mathrm{~cm}$ & Roots $20-40 \mathrm{~cm}$ & Roots total & Total \\
\hline & \multicolumn{5}{|c|}{ (g plant $\left.^{-1}\right)$} \\
\hline 0 & $3.87 \pm 1.26$ & $2.20 \pm 0.86$ & $0.68 \pm 0.27$ & $2.88 \pm 1.03$ & $6.75 \pm 2.28$ \\
\hline 140 & $3.34 \pm 0.31$ & $2.11 \pm 0.12$ & $1.55 \pm 0.37$ & $3.66 \pm 0.37$ & $6.99 \pm 0.68$ \\
\hline 280 & $3.53 \pm 1.93$ & $1.96 \pm 1.97$ & $1.24 \pm 1.06$ & $3.20 \pm 2.98$ & $6.73 \pm 4.80$ \\
\hline 560 & $5.30 \pm 2.51$ & $2.56 \pm 1.38$ & $1.35 \pm 0.90$ & $3.92 \pm 2.28$ & $9.22 \pm 4.78$ \\
\hline 1280 & $3.57 \pm 2.06$ & $1.94 \pm 0.83$ & $0.21 \pm 0.20$ & $2.14 \pm 1.01$ & $5.71 \pm 3.05$ \\
\hline
\end{tabular}

Mean \pm standard deviation 

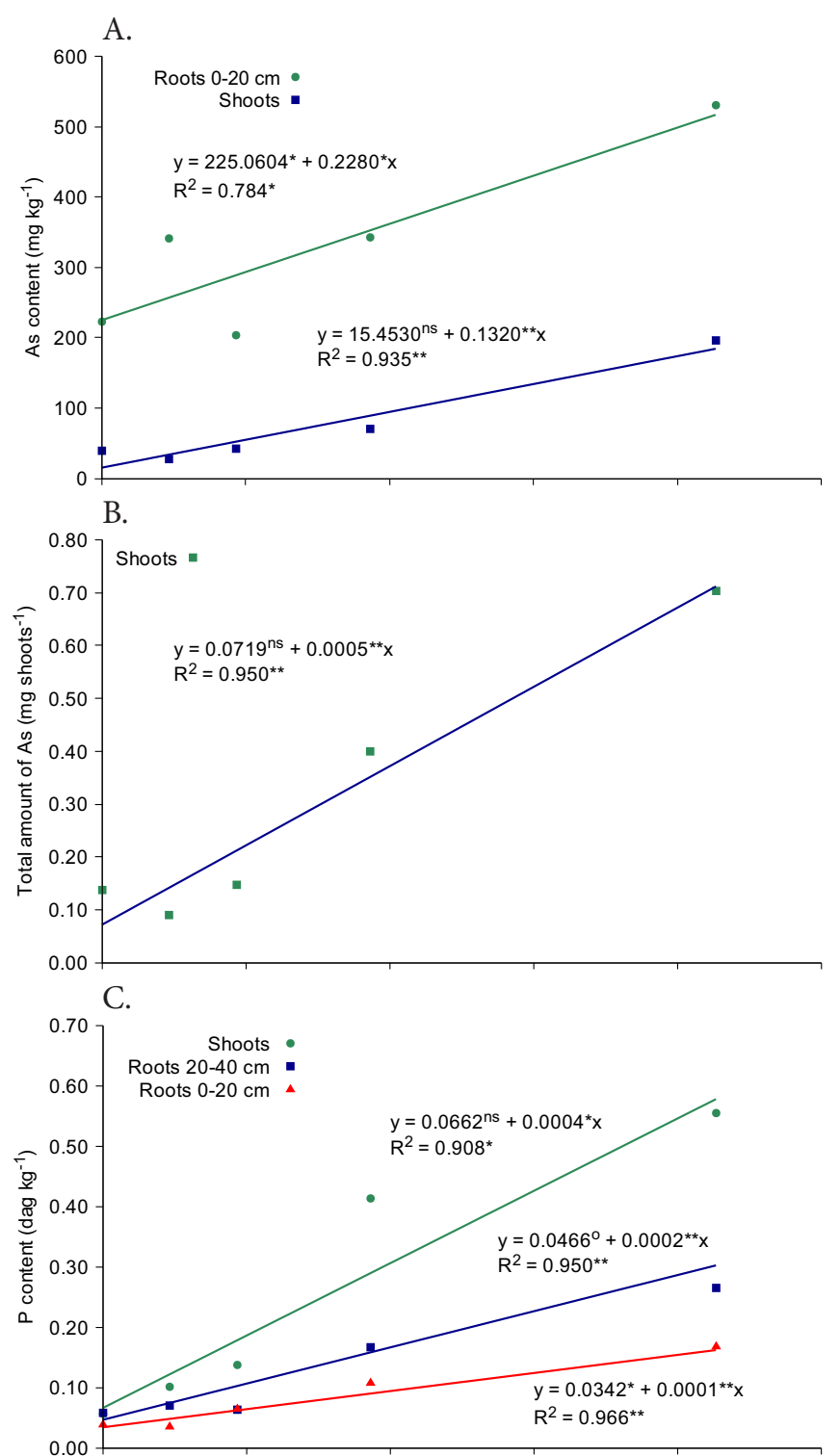

0.00

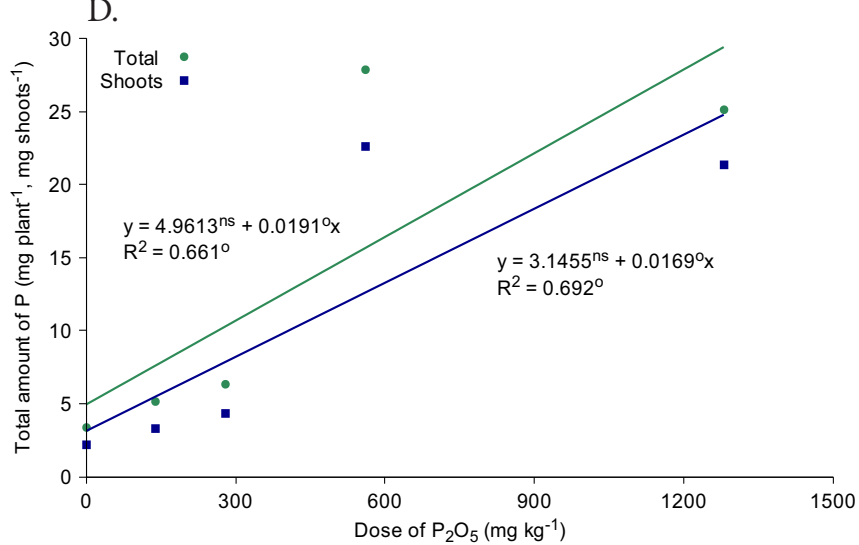

ns not significant. ${ }^{0},{ }^{*},{ }^{* *}$ significant at $0.10,0.05$ and 0.01 probability level, respectively

Figure 1. Contents and total amounts of $A$ s and $P$ in shoot and root dry matter (in the layers of 0-20 and 20-40 cm) of vetiver plants evaluated as a function of the applied phosphorus doses

generated by the addition of $\mathrm{P}$, as occurs with the cations of the soil (Ferreira et al., 2009).

Due to the mass effect, the P may have displaced As from the sorption sites of the particles, increasing the concentrations of the metalloid in the solution (Smith et al., 2002). Consequently, greater amounts of As were absorbed by the plants with the increment in $\mathrm{P}$ doses.

The plants accumulated As predominantly in the roots (Figure 1), corroborating with Moreno-Jiménez et al. (2012). Unlike P, As has low mobility in the plants, except in hyperaccumulator species (Zhao et al., 2008). The explanation for the limited translocation is that the arsenate is rapidly reduced to arsenite in the roots and, then, is complexed and sequestered in the vacuoles of root cells, which may reduce its translocation (Su et al., 2008; Zhao et al., 2008). Thus, the lower translocation may be associated with mechanisms of defense of the plants.

The tolerance of plants is related to the maintenance of the photosynthetic functions. The lower the As translocation, the lower the damage on photosynthetic rate and the higher the tolerance of the plant (Nascimento, 2007). In addition, arsenate compromises ATP biosynthesis, altering the energetic flow of plant cells (Meharg \& Hartley-Whitaker, 2002).

At the end of the experimental period, the content of As available in the substrate decreased with the increase in $\mathrm{P}$ doses (Figure 2). Such reduction can be attributed mainly to the greater absorption by the plants and the increment in $\mathrm{pH}$ with the increase in the doses. Higher $\mathrm{pH}$ values favor iron precipitation and, consequently, the reduction in As mobilization due to the adsorption or coprecipitation in the iron oxyhydroxides (Andrade et al., 2008). Thus, plants absorbed more As even with the reduction of its availability at the highest $\mathrm{P}$ doses, which reinforces the theory of the mass effect.

The oxidation of sulfide minerals accelerates the process of acidification. The reduction in $\mathrm{pH}$, in turn, accelerates the oxidation of sulfide minerals, increasing the activity of the elements As, Fe and $\mathrm{S}$ in solution. Higher $\mathrm{pH}$ inhibits the oxidation of pyrite $\left(\mathrm{FeS}_{2}\right)$ and reduces the solubility of the metals (Simmons et al., 2002). Therefore, the reduction in the available contents of As, Fe and S in the substrate due to the increment in the doses of $\mathrm{P}$, at least in part, results from increments in $\mathrm{pH}$.

The EC did not show significant responses to the $\mathrm{P}$ doses, varying from 5.78 to $9.32 \mathrm{dS} \mathrm{m}^{-1}$ in the layer of $0-10 \mathrm{~cm}$, from 2.53 to $3.00 \mathrm{dS} \mathrm{m}^{-1}$ in the layer of $10-20 \mathrm{~cm}$ and from 2.56 to 3.29

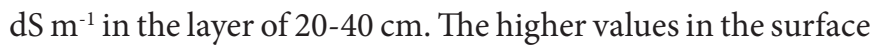
layer may be a result of the capillary rise of the saline solution. Different from what normally occurs in cultivated soils, sulfate salts are the main responsible for the EC in the studied substrate and come from the oxidation of sulfide minerals.

In dry periods in which the evaporation exceeds rainfall, there is the crystallization of salts on the surface of the tailings in Paracatu, which is a limitation to the revegetation of the disposal area. In various plots, there were saline accumulations forming a whitish crust of calcium sulfate on the surface.

The water restriction was imposed in order to verify whether the vetiver crop would survive to the low water availability, as occurs in Paracatu. The plants responded to the water restriction through the wilting of the leaves, but this symptom was not severe to the point of compromising the survival of the plants. 


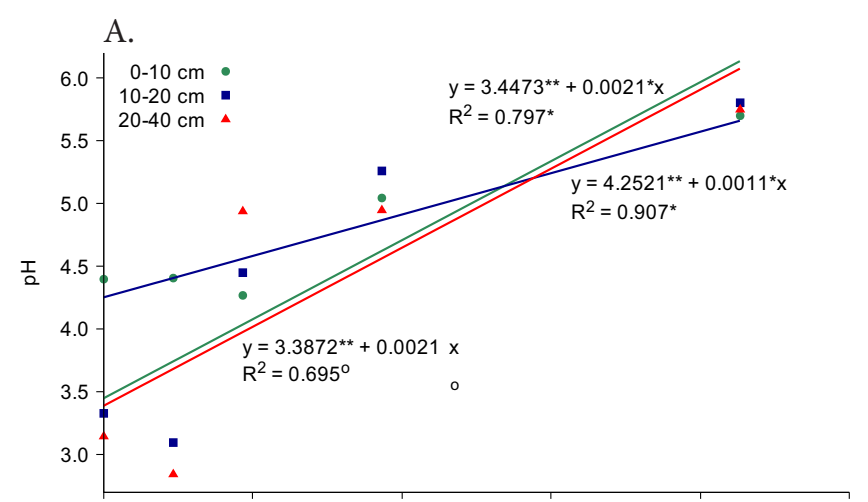

B.
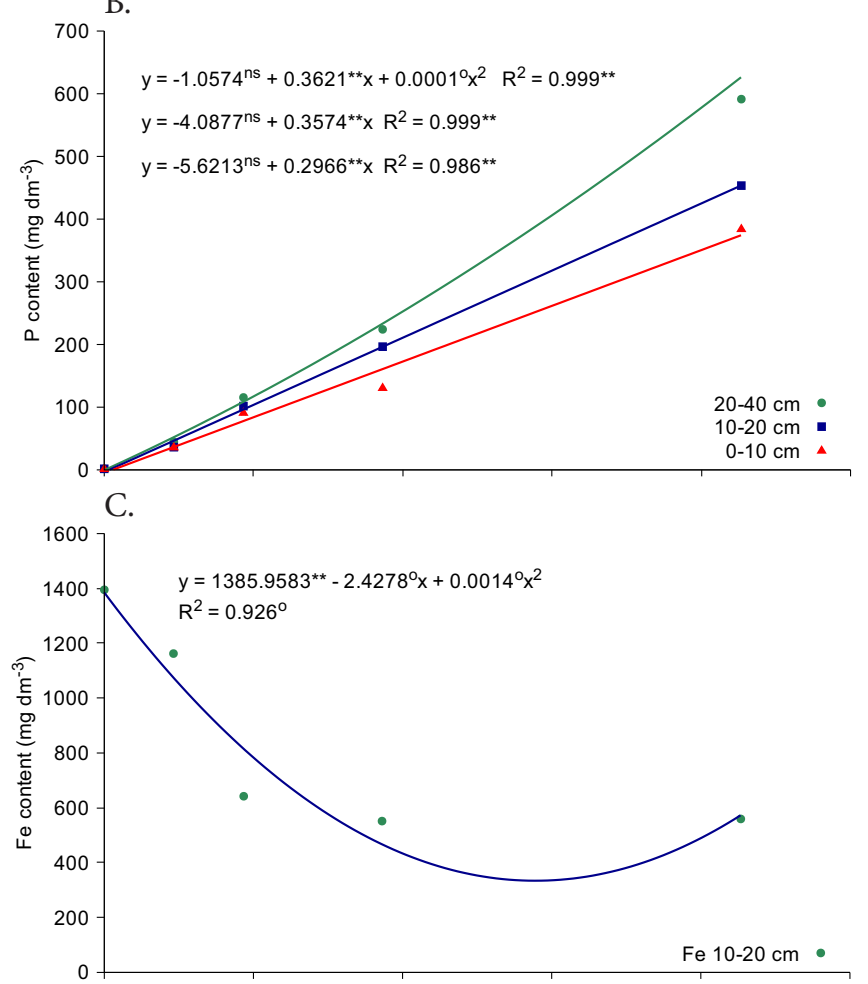

D.

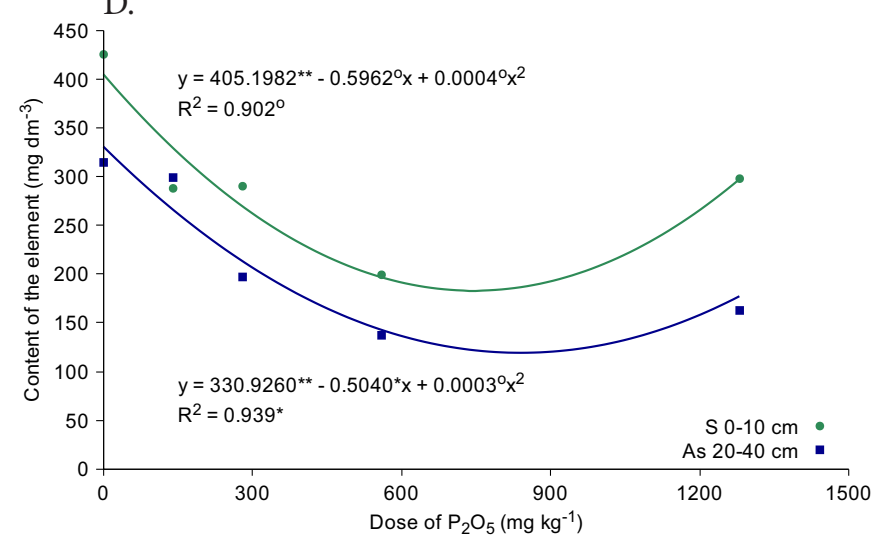

$0,{ }^{*},{ }^{* *}$ significant at $0.10,0.05$ and 0.01 , respectively

Figure 2. Values of $\mathrm{pH}$ and contents of $\mathrm{P}, \mathrm{Fe}, \mathrm{S}$ and $\mathrm{As}$ in the studied substrate, in the three layers evaluated, as a function of the applied phosphorus doses

\section{Conclusions}

1. The highest $\mathrm{P}$ dose tested $\left(1280 \mathrm{mg} \mathrm{kg}^{-1}\right.$ of $\left.\mathrm{P}_{2} \mathrm{O}_{5}\right)$ increases As toxicity in vetiver; despite the improvements in the chemistry of the substrate, the highest dose favors As absorption even with the reduction of its availability in solution.
2. Under the evaluated conditions, the dose of $560 \mathrm{mg} \mathrm{kg}^{-1}$ of $\mathrm{P}_{2} \mathrm{O}_{5}$ is the most adequate for the fertilization of vetiver aiming at the revegetation of the substrate.

3. Under the evaluated conditions, vetiver survives to the low water availability and possibly will also survive in the driest period of the year in Paracatu.

\section{ACKnowledgments}

To the Kinross Gold Corporation, for providing the materials and resources. To the Coordination for the Improvement of Higher Education Personnel (CAPES) and the National Council for Scientific and Technological Development (CNPq), for the scholarship.

\section{Literature Cited}

Alvarez V., V. H.; Novais, R. F.; Barros, N. F.; Cantarutti, R. B.; Lopes, A. S. Interpretação dos resultados das análises de solos. In: Ribeiro, A. C.; Guimarães, P. T. G.; Alvarez V., V. H. (ed.). Recomendações para o uso de corretivos e fertilizantes em Minas Gerais. 5a aproximação. Viçosa: CFSEMG, 1999. p.25-32.

Andrade, R. P.; Figueiredo, B. R.; Mello, J. W. V.; Santos, J. C. Z.; Zandonadi, L. U. Control of geochemical mobility of arsenic by liming in materials subjected to acid mine drainage. Journal Soils Sediments, v.8, p.123-129, 2008. http://dx.doi.org/10.1065/ jss2008.03.283

Brasil. Ministério do Meio Ambiente. Conselho Nacional de Meio Ambiente, CONAMA. Resolução CONAMA n 420/2009, de 30 de dezembro de 2009 - In: Resoluções, 2009. <http://www.mma. gov.br/port/conama/legiabre.cfm?codlegi=620>. 9 Mai. 2016.

Campos, M. L.; Guilherme, L. R. G.; Visiolli, E.; Antunes, A. S.; Curi, N. C.; Marques, J. J.; Silva, M. L. N. Força iônica da solução de equilíbrio na adsorção de arsênio em Latossolos brasileiros. Pesquisa Agropecuária Brasileira, v.41, p.457-460, 2006. http:// dx.doi.org/10.1590/S0100-204X2006000300012

Choi, J. M.; Latigui, A.; Lee, C. W. Visual symptom and tissue nutrient contents in dry matter and petiole sap for diagnostic criteria of phosphorus nutrition for 'Seolhyang' strawberry cultivation. Horticulture Environmental Biotechnology, v.54, p.52-57, 2013. http://dx.doi.org/10.1007/s13580-013-0130-y

EMBRAPA - Empresa Brasileira de Pesquisa Agropecuária. Centro Nacional de Pesquisa de Solos. Manual de métodos de análise de solo. 2.ed. Rio de Janeiro: Embrapa CNPS, 1997. 212p.

Farias, D. R.; Oliveira, F. H. T.; Santos, D.; Arruda, J. A.; Hoffmann, R. B.; Novais, R. F. Fósforo em solos representativos do estado da Paraíba. I - Isotermas de adsorção e medidas do fator capacidade de fósforo. Revista Brasileira de Ciência do Solo, v.33, p.623-632, 2009. http://dx.doi.org/10.1590/S010006832009000300015

Ferreira, E. V. O.; Anghinoni, I.; Carvalho, P. C. F., Costa, S. E. V. G. A.; Cao, E. G. Concentração do potássio do solo em sistema de integração lavoura-pecuária em plantio direto submetido a intensidades de pastejo. Revista Brasileira de Ciência do Solo, v.33, p.1675-1684, 2009. http://dx.doi.org/10.1590/S010006832009000600016 
Hinsinger, P.; Herrmann, L.; Lesueur, D.; Robin, A.; Trap, J.; Waithaisong, K.; Plassard, C. Impact of roots, microorganisms and microfauna on the fate of soil phosphorus in the rhizosphere. In: Plaxton, W. C.; Lambers, H. (ed.). Annual plant reviews v.48: Phosphorus metabolism in plants. Hoboken: John Wiley \& Sons, 2015. Cap.13, p.377-407. http://dx.doi. org/10.1002/9781118958841.ch13

Lei, M.; Wan, X. M.; Huang, Z. C.; Chen, T. B.; Li, X. W.; Liu, Y. R. First evidence on different transportation modes of arsenic and phosphorus in arsenic hyperaccumulator Pteris vittata. Environmental Pollution, v.161, p.1-7, 2012. http://dx.doi. org/10.1016/j.envpol.2011.09.017

Liu, X.; Zhang, S.; Shan, X.; Zhu, Y. G. Toxicity of arsenate and arsenite on germination, seedling growth and amylolytic activity of wheat. Chemosphere, v.61, p.293-301, 2005. http://dx.doi.org/10.1016/j. chemosphere.2005.01.088

Meharg, A. A.; Hartley-Whitaker, J. Arsenic uptake and metabolism in arsenic resistant and nonresistant plant species. New Phytologist, v.154, p.29-43, 2002. http://dx.doi.org/10.1046/ j.1469-8137.2002.00363.x

Melo, R. F.; Dias, L. E.; Mello, J. W. V.; Oliveira, J. A. Potencial de quatro espécies herbáceas forrageiras para fitorremediação de solo contaminado por arsênio. Revista Brasileira de Ciência do Solo, v.33, p.455-465, 2009. http://dx.doi.org/10.1590/S010006832009000200023

Moreno-Jiménez, E.; Esteban, E.; Peñalosa, J. M. The fate of arsenic in soil-plant systems. Reviews of Environmental Contamination and Toxicology, v.215, p.1-37, 2012. http://dx.doi.org/10.1007/978-14614-1463-6_1

Nascimento, K. J. T. Fotossíntese, trocas gasosas e respostas antioxidativas em Canavalia ensiformis e Stizolobium aterrimum submetidas a níveis tóxicos de arsênio. Viçosa: UFV, 2007. 36p. Dissertação Mestrado
Ruiz, H. A. Incremento da exatidão da análise granulométrica do solo por meio da coleta da suspensão (silte + argila). Revista Brasileira de Ciência do Solo, v.29, p.297-300, 2005. http://dx.doi. org/10.1590/S0100-06832005000200015

Schneider, J.; Oliveira, L. M.; Guilherme, L. R. G.; Stürmer, S. L.; Soares, C. R. F. S. Espécies tropicais de pteridófitas em associação com fungos micorrízicos arbusculares em solo contaminado com arsênio. Química Nova, v.35, p.709-714, 2012. http://dx.doi. org/10.1590/S0100-40422012000400010

Simmons, J.; Ziemkiewicz, P.; Black, D. C. Use of steel slag leach beds for the treatment of acid mine drainage. Mine Water and the Environment, v.21, p.91-99, 2002. http://dx.doi.org/10.1007/s102300200024

Singh, S. K.; Juwarkar, A. A.; Kumar, S.; Meshram, J.; Fan, M. Effect of amendment on phytoextraction of arsenic by Vetiveria zizanioides from soil. International Journal of Environmental Science and Technology, v.4, p.339-344, 2007. http://dx.doi.org/10.1007/BF03326291

Smith, E.; Naidu, R.; Alston, A. M. Chemistry of inorganic arsenic in soils: II. Effect of phosphorus, sodium, and calcium on arsenic sorption. Journal of Environmental Quality, v.31, p.557-563, 2002. http://dx.doi.org/10.2134/jeq2002.0557

Su, Y. H.; McGrath, S. P.; Zhu, Y. G.; Zhao, F. J. Highly efficient xylem transport of arsenite in the arsenic hyperaccumulator Pteris vittata. New Phytologist, v.180, p.434-441, 2008. http://dx.doi. org/10.1111/j.1469-8137.2008.02584.x

Tedesco, M. J.; Gianello, C.; Bissani, C. A.; Bohnen, H.; Volkweiss, S. J. Análise de solo, plantas e outros materiais. Porto Alegre: UFRGS, 1995. 174p.

Tu, C.; Ma, L. Q. Effects of arsenate and phosphate on their accumulation by an arsenic-hyperaccumulator Pteris vittata L. Plant and Soil, v.249, p.373-382, 2003. http://dx.doi.org/10.1023/A:1022837217092

Zhao, F. J.; Ma, J. F.; Meharg, A. A.; Mcgrath, S. P. Arsenic uptake and metabolism in plants. New Phytologist, v.181, p.777-794, 2008. http://dx.doi.org/10.1111/j.1469-8137.2008.02716.x 